\title{
Pengaruh Pemberian Ekstrak Air Biji Pepaya (Carica papaya L.) terhadap Stuktur Mikroanatomi Intestinum Tenue Mencit (Mus musculus L.) Betina
}

\section{Effect Of Papaya Seed Water Extract (Carica papaya L.) Treatment On The Microanatomy Structure Of Small Intestines Of Female Mice (Mus musculus L.)}

\author{
Ibnu Thoriq Hidayat, Agung Janika Sitasiwi*, Siti Muflichatun Mardiati \\ Program Studi Biologi, Fakultas Sains dan Matematika, Universitas Diponegoro, Semarang \\ *Email: ajssiwi@yahoo.com
}

Diterima 26 November 2020 / Disetujui 17 Maret 2021

\begin{abstract}
ABSTRAK
Ekstrak biji Pepaya (Carica papaya L.) mengandung saponin, alkaloid, flavonoid, dan tannin biasa digunakan sebagai bahan obat tradisional. Ekstrak ethanol biji papaya menunjukkan reaksi penghambatan pada kontraksi jejunum dan secara signifikan bersifat irreversible. Penelitian ini bertujuan untuk menguji pengaruh pemberian ekstrak air biji pepaya terhadap struktur mikroanatomi intestinum mencit (Mus musculus L.). Penelitian ini menggunakan Rancangan Acak Lengkap dengan 4 perlakuan yaitu P0 (akuades), P1 (1,4 mg/0,5 $\mathrm{ml})$, P2 $(3,5 \mathrm{mg} / 0,5 \mathrm{ml})$ dan P3 $(7 \mathrm{mg} / 0,5 \mathrm{ml})$. Perlakuan dilakukan secara oral selama 21 hari. Pemberian pakan secara ad libitum. Intestinum tenue diisolasi sepanjang $2 \mathrm{~cm}$ dari lambung sepanjang $1 \mathrm{~cm}$ kemudian di buat sediaan histologis dengan metode parafin dengan tebal sayatan $5 \mu \mathrm{m}$ dan pewarnaan Hemaktosilin dan Eosin (H\&E). Pengukuran panjang vili dan diameter intestinum tenue dilakukan pada 3 sayatan di setiap 3 sediaan histologis intestinum tenue. Data dianalisis dengan uji Anova, dilanjutkan dengan uji Duncan dengan taraf signifikansi 5\%. Hasil analisis menunjukan paparan bahan uji tidak berpengaruh signifikan ( $>0,05)$ terhadap panjang vili, dan bobot badan, tetapi menunjukan perbedaan yang signifikan $(\mathrm{p}, 0.05)$ pada diameter intestinum. Penelitian ini dapat disimpulkan bahwa pemberian ekstrak air biji pepaya selama 21 hari tidak mempengaruhi struktur intestinum tenue mencit sehingga aman digunakan sebagai bahan obat.
\end{abstract}

Kata kunci: Carica papaya, vili, intestinum tenue

\begin{abstract}
Papaya seed extract (Carica papaya L.) contains saponins, alkaloids, flavonoid, and tannins which are commonly used as an ingredient of traditional medicine. The ethanol extract of papaya seeds showed inhibitory reactions on jejunal contractions and was significantly irreversible. This study aims to examine the effect of papaya seed water extract on the intestine structure of female mice (Mus musculus L.). The Completely Randomized Design with 4 treatments namely P0 (distilled water), P1 (1.4 mg / $0.5 \mathrm{ml})$, P2 (3.5 $\mathrm{mg} / 0.5 \mathrm{ml})$ and P3 (7 mg / $0.5 \mathrm{ml})$ was used as axperimental design. The treatment was given orally for 21 days. Feeding and drinking are done in ad libitum. Small intestine was isolated as long as $2 \mathrm{~cm}$ from the stomach as long as $1 \mathrm{~cm}$ and then made histological preparations by the paraffin method with $5 \mu \mathrm{m}$ in thickness incision and staining of Hematoxyllin and Eosin (H\&E). Measurements of villous length and diameter of small intestine were performed in 3 incisions in every 3 histological small intestine preparations. Data were analyzed by Anova test, followed by Duncan Mean Range test with a significance level of 5\%. The analysis showed that the exposure of the papaya seed extract had no significant effect ( $p>0.05)$ on villi length, and body weight, but had significant effect $(\mathrm{p}<0.05)$ on intestines diameter.. It could be concluded that the treatment of papaya seed water extract for 21 days does not affect the structure of mice small intestine, so it is safe to use as an ingredient of traditional medicine.
\end{abstract}

Keywords: Carica papaya, villi, small intestine 


\section{PENDAHULUAN}

Penggunaan tanaman sebagai obat telah banyak dilakukan di Indonesia dengan resep yang sudah berjalan secara turun temurun. Hal tersebut juga didukung anggapan bahwa tanaman obat memiliki banyak kelebihan dibandingkan dengan obat kimia, misalnya efek samping yang relatif kecil, adanya aksi sinergis beberapa komponen dalam satu bahan, beberapa efek yang dihasilkan oleh satu jenis tanaman, serta kesesuaian untuk pengobatan penyakit degenerative (Kaur et al., 2011). Salah satu tanaman obat yang terdapat di Indonesia adalah tanaman pepaya (Walansedow dkk, 2016).

Tanaman pepaya menurut Walansedow dkk. (2016) sudah dimanfaatkan dalam berbagai bidang, baik sebagai bahan makanan atau sebagai bahan obat tradisional, tetapi pemanfaatan biji pepaya belum banyak diketahui masyarakat. Afolabi et al. (2011) menyatakan bahwa biji papaya berpotensi sebagai obat tradisional karena memiliki senyawa yang berperan sebagai antioksidan. Beberapa penelitian menunjukkan bahwa ekstrak biji pepaya dapat digunakan sebagai antidiabetes (Venkasteshwarlu et al., 2013), antifertilitas (Uche-Nacwi et al., 2011; Ekhator and Shelu, 2015), mempengaruhi siklus estrus (Sitasiwi dan Mardiati, 2016).

Ikperne et al. (2011) menyatakan Carica papaya mengandung beberapa senyawa yang memiliki potensi farmasetika yang dapat mempengaruhi struktur dan fungsi organ dalam tubuh. Pemberian ekstrak tanaman papaya dalam konsentrasi yang rendahtidak menyebabkan efek samping pada tubuh, tetapi jika konsumsi dilakukan dalam waktu yang cukup panjang maka dapat bersifat toksik pada beberapa jaringan tubuh. Eke et al. (2014) dalam penelitiannya menyatakan ekstrak biji Carica papaya mengandung saponin, alkaloid, cardiacglycoside, tannin, dan anthrapuinnon. Saponin dapat bersifat sitotoksik dan mempengaruhi permeabilitas membran sel intestinum. Katzung (2002) menyatakan bahwa rusaknya membran sel mukosa intestinum dapat menyebabkan penurunan bobot organ intestinum, dan pengecilan ukuran intestinum.
Suarni (2018) menyatakan bahwa faktor yang harus dipertimbangkan dalam pemakaian obat tradisional adalah dosis dan juga cara konsumsi sediaan obat herbal. Pratignyo dkk. (2013) menyatakan konsumsi obat herbal per oral dalam aktivitas medis memiliki risiko yang rendah. Penelitian Mardiati dan Sitasiwi (2016) membuktikan bahwa pemberian ekstrak air biji pepaya pada dosis $10 \mathrm{mg}$ dan $50 \mathrm{mg} /$ hewan/hari secara oral tidak menunjukkan efek toksik, ditunjukan dengan bobot badan mencit yang masih dalam kisaran normal. Efek pemberian ekstrak biji pepaya dengan dosis sampai $7 \mathrm{mg} / \mathrm{ekor} / \mathrm{hari}$ telah terbukti tidak mempengaruhi bobot badan, tetapi perubahan struktur intestinum dengan pemberian dosis tersebut belum dikaji. Penelitian ini dilakukan untuk membuktikan bahwa ekstrak air biji pepaya (Carica papaya L.) yang dikonsumsi secara oral tidak berpengaruh terhadap panjang villi dan diameter intestinum tenue mencit.

\section{METODE PENELITIAN}

\section{Alat dan Bahan}

Alat yang diperlukan dalam penelitian ini adalah seperangkat kandang pemeliharaan mencit dengan ukuran $20 \mathrm{~cm} \times 30 \mathrm{~cm} x 10 \mathrm{~cm}$ (lebar $\mathrm{x}$ panjang $\mathrm{x}$ tinggi), Bahan yang diperlukan dalam penelitian ini adalah hewan uji berupa mencit (Mus musculus L.) galur Swiss Webster betina berumur 2 bulan dengan bobot badan berkisar 25 gram. Bahan uji berupa biji $C$. papaya yang didapat dari daerah Gedawang, BanyumanikSemarang, akuades, garam fisiologis, larutan fiksatif, Buffer Neutral Formalin (BNF), parafin, larutan xylol, toluol, alkohol bertingkat (30\%, $40 \%, 50 \%, 60 \%, 70 \%, 80 \%, 90 \%, 96 \%$ ), hemaktosilin, eosin dan canada balsam.

\section{Pembuatan Ekstrak Biji Pepaya}

Biji pepaya dicuci bersih dengan air mengalir. Biji yang sudah dicuci, segera dikeringkan dalam oven pada suhu $45-50{ }^{0} \mathrm{C}$ selama 4-5 hari. Kriteria biji yang telah kering dilakukan dengan penimbangan biji setiap hari, apabila selama $3 x$ penimbangan berat biji tetap 
atau tidak menunjukkan perubahan lagi, maka dapat dipastikan bahwa biji sudah kering. Selanjutnya biji yang telah kering dibuat tepung dengan cara dihancurkan menggunakan blender. Tepung biji pepaya kemudian diayak. dengan mesh berukuran mesh 20. Tepung ditimbang sesuai dosis yang ditentukan untuk perlakuan.

\section{Menentukan Konsentrasi Bahan Uji}

Dosis bahan uji yang diberikan adalah 1,4; 3,5 mg dan $7 \mathrm{mg}$./ekor/hari. Bahan uji disiapkan dengan membuat larutan stok untuk pemberian bahan uji dalam 3 hari, sesuai dengan dosis dan jumlah hewan uji pada setiap kelompok perlakuan. Penimbangan biji papaya kering dilakukan dengan penghitungan besarnya dosis harian yaitu $1.4 \mathrm{mg}$ x 4 (jumlah ulangan hewan uji) $\mathrm{x} 3$ hari pemberian. Penimbangan dan persiapan juga dilakukan untuk dosis 3.5 mg/ekor hari serta $7 \mathrm{mg} / \mathrm{ekor} / \mathrm{hari}$ dengan cara yang sama. Bahan uji yang telah ditimbang dilarutkan dalam air mendidih sebanyak $0,5 \mathrm{ml}$ (volume yang diberikan pada tiap ekor) $\mathrm{x}$ jumlah ulangan hewan uji x 3 hari paparan sehingga setiap dosis bahan uji dilarutkan pada air mendidih sebanyak $6 \mathrm{ml}$. Larutan stok yang telah dibuat, disimpan dalam lemari pendingin pada temperatur $4{ }^{\circ} \mathrm{C}$ sampai waktu paparan bahan uji. Pemberian bahan uji dilakukan setelah larutan stok dikeluarkan dari lemari pendingin dan dibiarkan dalam ruangan sampai mencapai suhu kamar (sesuai metode Sitasiwi dan Mardiati, 2016).

\section{Cara Perlakuan Hewan Uji}

Mencit (Mus musculus L.) diaklimasi dalam kandang pemeliharaan selama 2 minggu, sebelum diberi perlakuan. Mencit diberi pakan standar berupa pakan merk Hi-Provite dengan kode 594. Air minum berasal dari air kran. Pemberian pakan dan minum dilakukan secara ad libitum. Kondisi pemeliharaan hewan dalam kondisi laboratorium yang terkontrol, yaitu temperatur berkisar $26^{\circ} \mathrm{C}$ dan kelembaban 75 $80 \%$.
Pemberian perlakuan oral dengan volume $0,5 \mathrm{ml} / \mathrm{h}$ hewan uji, pada sore hari (jam 15.0016.00), selama 21 hari berturut-turut. Bobot badan mencit diukur sebelum pemberian bahan uji serta selama pemberian bahan uji setiap 7 hari sekali. Penentuan konsumsi pakan harian dilakukan dengan mengukur rerata selisih pakan yang diberikan dan jumlah pakan yang tersisa dalam waktu tiga hari. Konsumsi minum diukur setiap hari dengan cara mengukur selisih volume air yang dimasukan dengan volume air yang tersisa dalam botol minum.

Isolasi intestinum dilakukan pada hari ke22, diawali dengan melakukan pembiusan hewan uji menggunakan chloroform, selanjutnya dibedah dari abdomen bagian bawah. Intestinum yang digunakan untuk pembuatan sediaan histologi adalah intestinum tenue, diisolasi dengan memotong bagian tersebut sepanjang 1 $\mathrm{cm}$. Potongan intestinum dicuci dengan larutan $\mathrm{NaCl}$ fisiologis kemudian dimasukkan ke dalam botol berisi larutan fiksatif BNF. Perendaman dalam larutan BNF dilakukan setidaknya 1 malam, selanjutnya diproses untuk dibuat preparat dengan metode parafin dan pewarnaan Hematoksilin Eosin dengan ketebalan sayatan 5 $\mu \mathrm{m}$.

Pengamatan sediaan histologis dilakukan dengan mikroskop pada perbesaran $10 \mathrm{X} 40$. Potongan organ intestinum tenue diamati struktur mikroanatomi serta dilakukan pengukuran diameter serta panjang villi.

Data panjang vili, diameter intestinum serta bobot badan dianalisis dengan Analysis of Variance (ANOVA) dengan taraf signifikansi 5\%. Data diameter intestinum menujukan perbedaan signifika shingga dilanjutkan dengan uji Duncan Mean Range Test dengan taraf signifikansi 0.5\% (Payadnya dan Jayantika, 2018).

\section{HASIL DAN PEMBAHASAN}

Hasil penelitian mengenai perubahan panjang vili dan diameter intestinum tenue mencit (Mus musculus L.) betina setelah pemberian ekstrak air biji pepaya (Carica papaya L.) dapat dilihat pada tabel 1. Hasil ANOVA pengaruh pemberian ekstrak air biji pepaya 
terhadap panjang vili intestinum tenue mencit menunjukkan bahwa bahan uji yang diberikan memberi pengaruh yang tidak signifikan $(p>0,05)$ terhadap panjang vili intestinum tenue mencit. Hal tersebut dapat diartikan bahwa pemberian bahan uji berupa ekstrak air biji pepaya sampai dosis $7 \mathrm{mg} /$ ekor/hari tidak menyebabkan perubahan ukuran panjang vili intestinum secara signifikan.

Hasil analisis rerata panjang vili intestinum tenue mencit (Tabel 1) menunjukkan bahwa rerata panjang vili intestinum tenue hewan uji pada seluruh kelompok perlakuan tersebut masih dalam kisaran yang normal. Harahap (2017) menjelaskan bahwa tinggi vili pada rodentia kecil khususnya tikus dan mencit berkisar antara 200-
$500 \mu \mathrm{m}$. Struktur vili intestinum tenue yang diamati dalam penelitian ini dapat dilihat pada gambar 2. Tariq et al. (2015) menyatakan bahwa komponen fitokimia yang terkandung dalam ekstrak air biji papaya terdiri dari tanin dan saponin. Yıldırım and Kutlu (2015) menyatakan bahwa tanin dan saponin memiliki efek antikanker dengan menekan terjadinya proliferasi, beraksi dengan cara mengganggu stabilitas membran sel. Hasil penelitian ini memberikan bukti bahwa saponin dan tanin yang terkandung dalam ekstrak air biji pepaya sampai dosis 7 $\mathrm{mg} / \mathrm{ekor} / \mathrm{hari}$ tidak menyebabkan gangguan struktur sel-sel penyusun vili intestinum sehingga panjang vili intestinum mencit juga tidak menunjukkan perbedaan signifikan.

Tabel 1. Hasil analisis rerata panjang vili intestinum, diameter intestinum, dan bobot badan mencit (Mus musculus L.) setelah pemberian ekstrak air biji pepaya (Carica papaya L.) selama 21 hari

\begin{tabular}{|c|c|c|c|c|}
\hline \multirow[b]{2}{*}{ Variabel } & \multicolumn{4}{|c|}{ Perlakuan } \\
\hline & $\begin{array}{c}\mathrm{P} 0 \\
\overline{\mathrm{x}}+\mathrm{SD}\end{array}$ & $\begin{array}{c}\mathrm{P} 1 \\
\overline{\mathrm{y}}+\mathrm{SD}\end{array}$ & $\begin{array}{c}\mathrm{P} 2 \\
\overline{\mathrm{x}}+\mathrm{SD}\end{array}$ & $\begin{array}{c}\mathrm{P} 3 \\
\overline{\mathrm{x}}+\mathrm{SD}\end{array}$ \\
\hline Panjang Vili & $333,25^{\mathrm{a}} \pm 45.25$ & $395,77^{\mathrm{a}} \pm 73.32$ & $408,25^{\mathrm{a}} \pm 74,87$ & $460,30^{\mathrm{a}} \pm 119,69$ \\
\hline Intestinum $(\mu \mathrm{m})$ & & & & \\
\hline Diameter & $1637,33^{\mathrm{a}} \pm 158,31$ & $2189,05^{\mathrm{b}} \pm 174,81$ & $1816,79^{\mathrm{ab}} \pm 268,99$ & $1898,13^{\mathrm{a}} \pm 164,35$ \\
\hline Intestinum $(\mu \mathrm{m})$ & & & & \\
\hline $\begin{array}{l}\text { Bobot Badan } \\
(\mathrm{g})\end{array}$ & $25,17^{\mathrm{a}} \pm 0,45$ & $27,77^{\mathrm{a}} \pm 3,07$ & $26,67^{\mathrm{a}} \pm 0,85$ & $26,43^{\mathrm{a}} \pm 1,50$ \\
\hline $\begin{array}{r}\text { Keterangan: Angl } \\
\text { signif } \\
\text { kelon } \\
\text { bahar } \\
\mathrm{mg} / 0\end{array}$ & $\begin{array}{l}\text { g diikuti supersk } \\
\text { p }>0,05) \text {. P0 : } \mathrm{k} \\
\text { erlakuan bahan } \\
\text { onsentrasi } 3,5 \mathrm{~m} \\
\text { kor/hari }\end{array}$ & $\begin{array}{l}\text { yang sama pada } \\
\text { pok kontrol pe } \\
\text { konsentrasi } 1,4 \\
\text { ml/ekor/hari. F }\end{array}$ & $\begin{array}{l}\text { yang sama menur } \\
\text { bahan uji akuades } \\
, 5 \mathrm{ml} / \mathrm{ekor} / \mathrm{hari} \text {. } \\
\text { elompok perlakuan }\end{array}$ & $\begin{array}{l}\text { zan perbedaan tidak } \\
\text { ml/ekor/hari. P1 : } \\
\text { celompok perlakuan } \\
\text { an uji konsentrasi } 7\end{array}$ \\
\hline
\end{tabular}

Berdasarkan Hasil Analisis uji Duncan terhadap rerata ukuran diameter intestinum tenue mencit (Tabel 1), diketahui mencit pada kelompok perlakuan P1 berbeda signifikan dengan P0 dan P3, tetapi tidak berbeda signifikan dengan P2. Kelompok P0 menunjukkan perbedaan tidak signifikan dengan P2 dan P3. Kelompok P2 menunjukkan perbedaan tidak signifikan dengan P1. Struktur diameter intestinum tenue yang diamati dalam penelitian ini dapat dilihat pada gambar 2 .

Perbedaan diameter disebabkan karena perbedaan tebal lapisan muskularis dan materi yang berada di dalam rongga intestinum. Hasil penelitian ini menunjukkan diameter intestinum tenue berkisar $1.6-2.1 \mathrm{~mm}$. Casteleyn et al. (2010) menjelaskan bahwa diameter intestinum mencit berkisar antara $1 \mathrm{~mm}$ hingga $2 \mathrm{~mm}$, sehingga dapat dikatakan bahwa ukuran diameter intestinum masih dalam kisaran normal. Hasil penelitian ini juga menunjukan bahwa pemberian ekstrak air biji pepaya pada mencit dengan dosis $1,4 \mathrm{mg} / \mathrm{ekor} / \mathrm{hari}$ memberikan hasil terkuat dalam mempengaruhi diameter intestinum. Hal ini diduga karena pada dosis tersebut ekstrak air biji pepaya menyebabkan perubahan kontraksi lapisan muskularis intestinum sehingga menyebabkan penebalan lapisan muskularis yang menyebabkan perubahan diameter. 

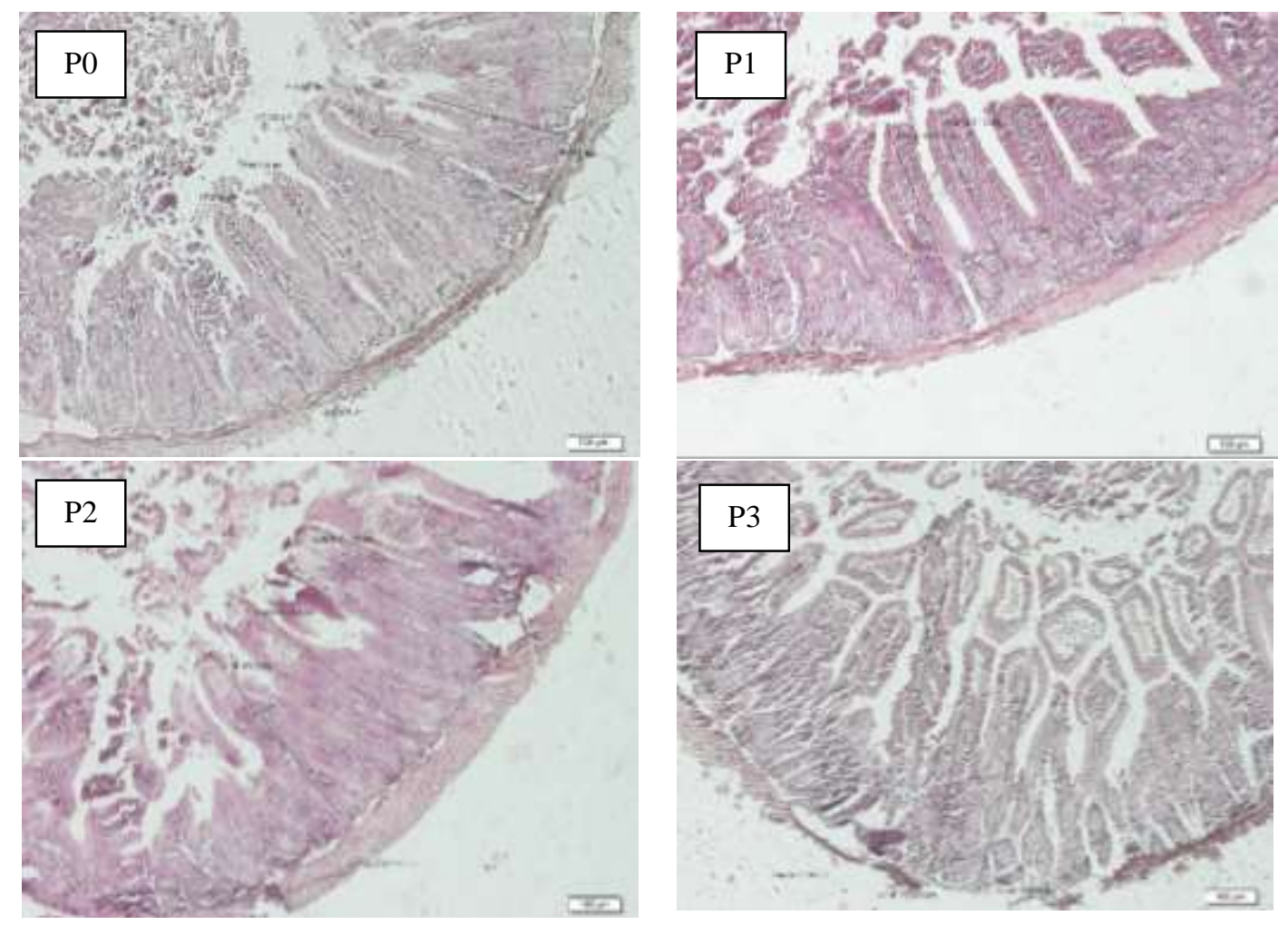

Gambar 1. Struktur vili Mencit (Mus musculus). Perbesaran 100x.

\begin{tabular}{lrr}
\multicolumn{3}{c}{ Maynard and Downes (2019) menyatakan } \\
lapisan muskularis intestinum dapat \\
mempengaruhi proses pencernaan dan
\end{tabular}
penyerapan nutrisi yang menyebabkan perubahan

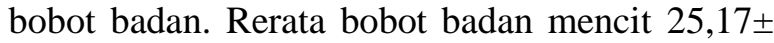
0,45 gram (P0) sampai 27,77 $\pm 3,07(\mathrm{P} 1)$ tetapi tidak menunjukkan perbedaan signifikan antar kelompok perlakuan. Hasil analisis rerata bobot badan mencit menunjukkan bahwa rerata bobot badan hewan uji pada seluruh kelompok perlakuan tersebut masih dalam kisaran yang normal. Hal tersebut sesuai dengan pendapat Hasanah (2015) yang menyatakan bahwa bobot badan mencit normal berkisar antara 18-35 gram. Perubahan bobot badan menggambarkan proses digesti yang berjalan dengan normal. Intestinum tenue merupakan bagian dari sistem digesti yang berperan dalam absorbsi nutrisi (Colville and Bassert, 2008). Rastogi (2007) menyatakan bahwa membran lapisan intestinum yang normal mendukung proses metabolisme yang dapat mempengaruhi pertambahan bobot badan. Data bobot badan juga menunjukkan fungsi intestinum tenue tidak terganggu pemberian bahan uji secara oral selama 21 hari sehingga tidak menyebabkan perubahan bobot badan hewan uji.

Saqui-Salces et al. (2017) menyatakan bahwa bobot badan genetik, jenis kelamin dan nutrisi. Penelitian ini menggunakan hewan uji mencit dengan strain dan jenis kelamin yang sama yaitu mencit Swiss Webster betina. Berdasarkan hal tersebut diduga bahwa komponen senyawa dalam ekstrak air biji papaya tidak mempengaruhi penyerapan komponen nutrisi dalam pakan sehingga tidak mempengaruhi bobot badan. Komponen nutrisi dalam ekstrak biji pepaya menurut (Tariq et al., 2015) memiliki jumlah yang seimbang yaitu protein (24.3\%), asam lemak (25.3\%) dan kabohidrat total $(32.5 \%)$ tetapi pemberian dosis yang rendah sampai $7 \mathrm{mg} / \mathrm{ekor} / \mathrm{hari}$ diduga tidak mempengaruhi metabolisme hewan uji sehingga tidak terjadi kenaikan bobot badan. Hal tersebut sejalan dengan penelitian Dhabadkar et al. (2015) yang membuktikan penggunaan biji pepaya sebagai obat tradisional mampu menekan obesitas sehingga tidak menyebabkan kenaikan bobot badan. 



Gambar 2. Diameter intestinum Mencit (Mus musculus). Perbesaran 40x.

\section{KESIMPULAN}

Hasil penelitian menunjukkan bahwa pemberian ekstrak air biji pepaya dengan dosis sampai $7 \mathrm{mg} / \mathrm{ekor} / \mathrm{hari}$ tidak berpotensi mempengaruhi struktur dan fungsi intestinum tenue mencit.

\section{UCAPAN TERIMA KASIH}

Penulis menyampaikan terima kasih kepada Dekan Fakultas Sain dan matematika Universitas Diponegoro yang telah memberikan dukungan dana penelitian melalui proyek DIPA Nomor: 1110EP/UN7.3.8/PG/2016 tanggal 11 Maret 2016.

\section{DAFTAR PUSTAKA}

Afolabi, I.S., S.M. Akuiyibo, S.O. Rotimi, A.O. Adeyemi, 2011. In vivo Evaluation of Lipid and Antioxidants qualities of Carica papaya Seed Oil. Journal of Natural Products. 4: 125-135.
Casteleyn, C., A. Rekecki, A. Van der Aa, P. Simoens, and V. de Broeck, 2010. Surface Area Assesment of The Murine Intestinal Tract as Apprerequisite for Oral Dose Translation fromm Mouse to Man. NCBI. 44(3): 176-83.

Colville, T, and J.M. Bassert, 2008. Chemical Anatomy and Physiology for Veterinary Technicians. MOSBY Elsevier. Missuori.

Dabhadkhar, D.K., V.G. Thakare, V.S. Zade, A.P. Charjan, M.M. Dhore \& S.M. Deosthale. 2015. Review on some ethnobotanical plants having antifertility activity in female albino rats. Int. Res. J. of Science and Engineering 3(2): 43-46.

Ekhator, C.N. and J.O.Shelu, 2015. An experimental study on the abortificient potentials of unripe seed extract of Carica papaya in Adult Female Wistar Rats. Open Science Journal of Pharmacy and Pharmacology. 3(6): 61-65.

Eke, O.N., A.U. Augustine, H.F. Ibrahim. 2014. Qualitative Analysis of Phytochemicals and Antibacterial Screening of Extracts of 
Carica papaya Fruit and Seeds. International Journal of Chemistry. 6(1): 48-56.

Hasanah U., Rusny dan M. Masri. 2015.Seminar Nasional Mikrobiologi Kesehatan dan Lingkungan: Analisis Pertumbuhan Mencit (Mus musculus L.) ICR dari Hasil Perkawinan Inbreeding dengan Pemberian Pakan AD1 dan AD2. Makassar, 29 Januari 2015.

Harahap, Ida Lestari. 2017. Efek Protektif Vitamin E pada Epitel Jejunum Tikus Putih (Rattus noregicus) yang Diinduksi Timbal Asetat. Jurnal Kedokteran Unram. 6(3): 18-23.

Ikperne, V.H., U.B. Ekaluo, M.E. Kooffreh, and O. Udensi, 2011. Phytochemical and Haematological Potential of Ethanol Seed leaf and Pulp Extract of Carica papaya (Linn,). Pakistan Journal of Biological Science. 14(6): 408-411.

Katzung, B.G. 2002. Farmakologi Dasar dan Klinik. Edisi 8. Penerbit Salemba Medika. Jakarta.

Kaur, R., R. Sharma, and R. Kharb, 2011.Rising trends Toward herbal contraceptives. Scholars Research Library. J. Nat. Prod. Plant Resour. 1(4): 5-12.

Maynard, R.L. and N. Downes. 2019. Alimentary Canal and Gastrointestinal Tract Anatomy and Histology of the Laaboratory Rat in Toxicology and Biomdical Research, 147158.

Mardiati S.M. dan A.J. Sitasiwi., 2016.Pertambahan Berat Badan Mencit (Mus musculus L.) Setelah Perlakuan Ekstrak Air Biji Pepaya (Carica papaya Linn.) Secara Oral Selama 21 Hari.Buletin Anatomi dan Fisiologi, 1(1): 7580.

Payadnya, I.P.A.A. dan I.G.A.N.T. Jayanitka, 2018. Penduan Penelitian Eksperimen beserta Analisis Statistik dengan SPSS. Penerbit Deepublish. Yogyakarta.

Pratignyo, R.B., J. Anzar, H.M. Nazir \& Theodorus. 2013. Efektifitas Asuhan Nutrisi Pediatrik Per oral untuk Mencegah
Malnutrisi Rumah Sakit. Sari Pediatri 15: 264-268.

Rastogy, S.C., 2008. Essentials of Animal Physiology. $4^{\text {th }}$ Ed. New Age International Publishers. California.

Saqui-Salces, X.M., A.C. Tsao, M.G. Gilliland, L. J. Merchant, 2017. Weight gain in mice on high caloric diet and chronically treated with omeprazole depends on sex and genetic background. Am. J. Physiol. Gastrointest. Liver Physiol. 312: G15G23.

Suarni, 2005, Tanaman Obat tak Selamanya Aman, http://pikiran- rakyat.com [diakses 25 Maret 2018].

Tariq, M.H., B. Ghaffar, T. Ahmed, A.Sultan, M. Irfan, and M.J. Farrukh, 2015. Phytochemical and Microbial evaluation of Different Chemical Extract of Papaya Seeds on Clinical Isolates of FGSH Hospital Islamabad. Int. J. Pharm. 5(1): 122-126.

Uche-Nwachi, E.O., C.v. Mitchell \& C. Mc.Ewen. 2011.Stereodegenic Enzime Histochemistry in the Testis of Sprague DAwley Rats Fllowing the Administration. of Water Extract from Carica papaya Seed. Africa Journal Tradir Complement Altern Med 8(1):69-78.

Venkateshwarlu, E., P. Dileep, R.K. Reddy, P. Sandhaya, 2013. Evaluation of Antidiabetic Activity of Carica papaya Seeds on Streptozocin Induced Type-II Diabetic Rats. Journal of Advanced Scientific Research. 4(2): 38-41.

Walansendow, R., M.R. Janette \& T.Lydia. 2016. Pengaruh pemberian ekstrak biji pepaya (Carica papaya L.) Terhadap kualitas spermatozoa tikus wistar (rattus norvegicus). Jurnal e-Biomedik (eBm) 4(1): 1-4.

Yildirim, I., and T. Kutlu, 2015. Anticancer Agents: Saponin and Tannin. Int. Journal of Biological Chemistry. 9 (6): 332-340 